\title{
Pretty People
}




\section{S T A R

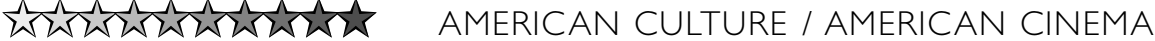 DE C A D ES}

Each volume in the series Star Decades: American Culture/American Cinema presents original essays analyzing the movie star against the background of contemporary American cultural history. As icon, as mediated personality, and as object of audience fascination and desire, the Hollywood star remains the model for celebrity in modern culture and represents a paradoxical combination of achievement, talent, ability, luck, authenticity, superficiality, and ordinariness. In all of the volumes, stardom is studied as an effect of, and influence on, the particular historical and industrial contexts that enabled a star to be "discovered," to be featured in films, to be promoted and publicized, and ultimately to become a recognizable and admiredeven sometimes notorious-feature of the cultural landscape. Understanding when, how, and why a star "makes it," dazzling for a brief moment or enduring across decades, is especially relevant given the ongoing importance of mediated celebrity in an increasingly visualized world. We hope that our approach produces at least some of the surprises and delight for our readers that stars themselves do.

ADRIENNE L. MCLEAN AND MURRAY POMERANCE SERIES EDITORS

Jennifer M. Bean, ed., Flickers of Desire: Movie Stars of the 1910s

Patrice Petro, ed., Idols of Modernity: Movie Stars of the 1920s

Adrienne L. McLean, ed., Glamour in a Golden Age: Movie Stars of the 1930s

Sean Griffin, ed., What Dreams Were Made Of: Movie Stars of the 1940s

R. Barton Palmer, ed., Larger Than Life: Movie Stars of the 1950s

Pamela R. Wojcik, ed., New Constellations: Movie Stars of the 1960s

James Morrison, ed., Hollywood Reborn: Movie Stars of the 1970s

Robert Eberwein, ed., Acting for America: Movie Stars of the 1980s

Anna Everett, ed., Pretty People: Movie Stars of the 1990s

Murray Pomerance, ed., Shining in Shadows: Movie Stars of the 2000s 


\section{Pretty People Movie Stars of the $1990 \mathrm{~s}$

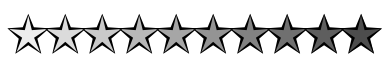

EDITED BY ANNA EVERETT 
LIBRARY OF CONGRESS CATALOGING-IN-PUBLICATION DATA

Pretty people : Movie stars of the 1990s / edited by Anna Everett.

p. cm. - (Star decades : American culture / American cinema)

Includes bibliographical references and index.

ISBN 978-0-8135-5244-6 (hardcover : alk. paper)

ISBN 978-0-8135-5245-3 (pbk. : alk. paper)

ISBN 978-0-8135-5325-2 (e-book)

1. Motion picture actors and actresses-United States-Biography. I. Everett, Anna, $1954-$

PN1998.2.P75 2012

$791.4302 ' 80922-\mathrm{dc} 23$

2011023339

A British Cataloging-in-Publication record for this book is available from the British Library.

This collection copyright $\odot 2012$ by Rutgers, The State University

Individual chapters copyright $\odot 2012$ in the names of their authors

All rights reserved

No part of this book may be reproduced or utilized in any form or by any means, electronic or mechanical, or by any information storage and retrieval system, without written permission from the publisher. Please contact Rutgers University Press, 100 Joyce Kilmer Avenue, Piscataway, NJ 08854-8099. The only exception to this prohibition is "fair use" as defined by U.S. copyright law.

Visit our Web site: http://rutgerspress.rutgers.edu

Manufactured in the United States of America 
For my darling mother, Lena. RIP 
